\title{
Nursing care for migrants in a refugee camp Dobová - Slovenia
}

\author{
5. Puteková, 0. Kabátová
}

Original Articles

Trnava University, Faculty of Health and Social Work,

Department of Nursing, Trnava, Slovakia

Submitted: 2.2.2016 Revised: 30.3.2016 Accepted: 15.4.2016

\section{Reviewers:}

A. Kalavska

Clinic for Travel medicine, Comenius University Bratislava, Slovakia

Daniel J. West

University of Scranton, Department of Health Administration and Human Resources, USA

\section{Key words:}

Nursing. Care. Migrant. Nursing diagnoses. Volunteering

\section{Abstract:}

The aim of the study was to map the range of the most frequent nursing diagnoses in migrants migrating through Slovenia to Austria and Germany. Data collection took place in the refugee camp in Dobová (Slovenia). We found out that the largest number of migrants suffered from acute pain, fatigue, hyperthermia, diarrhoea, impaired skin integrity, lack of sleep, impaired gait and reduced volume of body fluids. Frequent nursing diagnoses related to psychological problems were hopelessness and helplessness, resulting from difficult life situations.

\section{Introduction}

Nursing is not only an extremely demanding work, but also a stimulating and joyful mission, which combines professional performance with a willingness to help people and work towards their benefit. Linking knowledge and practical skills with deep altruism inherent in the loving care is a typical feature of contemporary nursing. Nursing is science and art at the same time. A good nurse is a gift of God; fulfils several functions and missions (Novotny, 2006). A nurse must be prepared to perform tasks professionally, theoretically and practically in favour of a recovery and health promotion. A nurse is able to find new creative approaches in the provision of nursing care and to gain new experience within the profession (Wiczmándyová \& Tkáčová, 2010). From 25th to 27th, December, 2015 our main mission was to provide care for people with difficult destiny - migrants from both somatic and psychological aspects.

\section{Patients and Methods}

The main objective of the study was to map the most common nursing diagnosis for migrants migrating through Slovenia to Austria and Germany. Migrants coming to our refugee camp in the village of Dobová in Slovenia from Syria, Afghanistan and Iraq. Daily 3000 - 5000 migrants register in Dobová, which is the main crossing point on the Slovenian-Croatian border, 
from where most of them are transported to the village of Šentilj in northeast Slovenia by train- near this village is a major railway border crossing to Austria. After registering, humanitarian aid workers provide food, clothing and medical care. Data collection took place from 25 th to 27 th, December, 2015, during which in two 12hour night shifts we treated about 250 people aged from 2 days to 67 years. Nursing diagnoses were specified on the basis of taxonomy NANDA International 20122014.

\section{Results and Discussion}

Help and assistance to migrants in the camp Dobová was provided by organizations such as the UNHCR which provides legal security and counselling, the Red Cross which provides social welfare, and civil protection unit, which provides functioning of the camp (electricity, benches, tents, tables). Medical assistance is provided by St. Elizabeth College of Health and Social Work's Tropic Team and its volunteers as doctors, nurses and medical students. Volunteering and nursing are linked since ancient times. The emergence of volunteering in Slovakia historically falls into the Middle Ages and was formed in first orphanages, hospices and shelters. Even then, the selflessly devoted religious helped the abandoned, the sick and dying (Dudeková, 1998). This period is defined as a charity nursing. Today's professional nursing broaden and improve the nursing process, which is the base of a detailed assessment of the patient and determination of the appropriate current or potential nursing diagnoses. Assessment of the patient is the cornerstone of nursing, of which the aim is to lead a systematic and integrated review (Martinková, 2015). Nurses who apply their knowledge and advanced experience as well as they cooperate with multidisciplinary and transdisciplinary teams, play a very important role in accurate assessment outcomes (Grešš Halasz \& Wiczmándyová, 2015). Table 1 shows the range of the most common nursing diagnoses occurring at the time of our operation in the refugee camp. In connection with the diagnosis of acute pain, the most frequent problem was headache, neck, abdomen and lower limb pain. The diagnosis impaired verbal communication mainly meant the language barrier. Within nursing assessment, we measured basic vital signs (blood pressure, pulse, body temperature, $\mathrm{O} 2$ saturation), blood glucose, treated wounds, focused on hydration of the patient, administered drugs orally, into ears, eyes, administered subcutaneous (insulin) and intramuscular injections or provided infusion therapy. Individual nursing interventions were carried out either on the basis of indications or in collaboration with a doctor.

\section{Tab. 1 The range of the most common nursing diagnoses in migrants}

\begin{tabular}{|l|}
\hline Nursing diagnoses (NANDA) \\
\hline Inefficient care for own health (00078) \\
\hline The risk of unstable glucose levels (00179) \\
\hline Reduced volume of body fluids (00027) \\
\hline Constipation (00011) \\
\hline Diarrhoea (00013) \\
\hline Lack of sleep (00098) \\
\hline Impaired gait $(00088)$ \\
\hline Fatigue (00093) \\
\hline Impaired verbal communication $(00051)$ \\
\hline Hopelessness (00124) \\
\hline Powerlessness (00125) \\
\hline Fear (00148) \\
\hline The risk of infection $(00004)$ \\
\hline Impaired integrity of the skin $(00046)$ \\
\hline Impaired integrity of tissues $(00042)$ \\
\hline Hyperthermia (00007) \\
\hline Acute pain (00123) \\
\hline Nausea (00134) \\
\hline
\end{tabular}


According to a study Krčméry et al. (2015), the most common medical diagnoses in migrants are infectious- origin inflammations of the upper respiratory tract, pneumonia, skin and soft tissues damages including wounds and insect bites, scabies; MRSA as a cause was found only in one case. Non-infectious diseases included hypertension, insomnia, diabetes, total exhaustion of the body, depression and neuropsychiatric disorders related to long-term stress.

\section{Conclusion}

The issue of refugees is a new social phenomenon which will require increased attention of social and health workers. Nurses play an important contributing role of a multidisciplinary team that appreciates patient with his religious beliefs, life values, customs, and aims to create conditions that meet individual's needs within care they provide. Therefore, in the context of migration and volunteering, multicultural nursing care is increasingly gaining prominence.

\section{References}

GREŠŠ HALÁSZ, B. WICZMÁNDYOVÁ, D. Advanced practice nurses in the context of multidisciplinarity, interdisciplinarity and transdisciplinarity. In A multidisciplinary cooperation in health: Proceedings of professional and scientific work. SKSaPA High Tatras. 2015, p. 122-125. ISBN 978-80-89542-49-9.

KRCMERY, V. et al. Respiratory infections after camping in free nature are the current diseases in Migrants to Austria and Germany via Hungary in September 2015: Experience from Röszke and Vámoszabadi. Clinical Social Work. 2015. 2, 5: 39-41.

MARTINKOVÁ, J. Physical assessment of the Elderly. In X. national conference nurses working in internal medicine. - Bratislava: Slovak Chamber of Nurses and Midwives, 2015. ISBN 978-80-89542-47-5. - CD-ROM; S. 21.

NOVOTNÝ, J. Nursing as humanitarian science. In Nursing. 2006. 8: 1 - 200.

NANDA INTERNATIONAL. Nursing diagnoses - Definition and classification 2012 - 2014. Prague: Grada. 584 pp. ISBN 978-80247-4328-8.

DUDEKOVÁ, G. Voluntary association in Slovakia in the past. Edition third sector and volunteering 4/1998, Bratislava: S.P.A.C.E. - Centre for the analysis of social policy.

WICZMÁNDYOVÁ, D., TKÁČOVÁ, L'. 2010. The socio-economic aspect of migration of nurses. And training in non-medical odborochProceedings of the 4th International Scientific Conference. Bratislava: SZU, 2010. ISBN 97880-89352-47-0, p.62-70.

\section{Corresponding author}

Silvia Puteková, Dr., Ph. D.

Department of Nursing

Trnava University in Trnava

Faculty of Health Sciences and Social Work

Univerzitné nám. 1

91843 Trnava, Slovak Republic

e-mail: silvia.putekova@truni.sk 